\title{
Das Anerkennungsprinzip im Kollisionsrechtssystem des internationalen Privatrechts
}

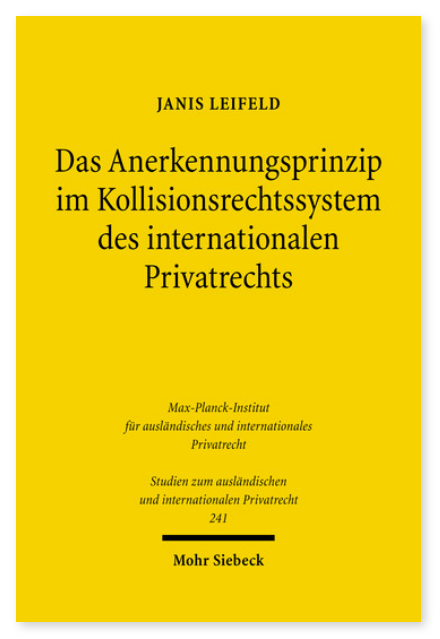

2010. XXI, 240 Seiten. StudIPR 241

ISBN 978-3-16-151426-5

DOI 10.1628/978-3-16-151426-5

eBook PDF 69,00€

ISBN 978-3-16-150416-7

fadengeheftete Broschur $69,00 €$
Die Freizügigkeit innerhalb der Europäischen Union nimmt stetig zu. Damit einher geht die Möglichkeit, im europäischen Ausland beispielsweise die Ehe zu schließen, eine Lebenspartnerschaft zu begründen oder einen Namen einzutragen. So selbstverständlich diese Optionen im immer enger zusammenwachsenden Europa heutzutage scheinen, so wenig geklärt ist bisher die Frage, ob die im europäischen Ausland begründeten Statusverhältnisse in Deutschland Wirksamkeit entfalten. Janis Leifeld geht diesem Problem sowohl aus europarechtlicher als auch aus international-privatrechtlicher Perspektive nach. Im Mittelpunkt stehen folgende Fragen: Sind in einem Mitgliedstaat begründete Statusverhältnisse von den anderen Staaten der Europäischen Union anzuerkennen? Wie kann die durch die europäischen Grundfreiheiten begründete Anerkennungspflicht kollisionsrechtlich umgesetzt werden? Wie fügt sich das Anerkennungsprinzip in die Dogmatik des internationalen Privatrechts ein?

Janis Leifeld Geboren 1980; 2001-06 Studium der Rechtswissenschaft in Tübingen; 2006-09 wiss. Mitarbeiter an der Universität Tübingen; derzeit Referendariat am LG Tübingen.

Jetzt bestellen:

https://mohrsiebeck.com/buch/das-anerkennungsprinzip-im-kollisionsrechtssystem-des-internationalen-privatrechts9783161514265?no_cache=1

order@mohrsiebeck.com

Telefon: $+49(0) 7071-923-17$

Telefax: $+49(0) 7071-51104$ 